\title{
Pembentukan Rapport di Kelas: Analisis Psikologi
}

\author{
Muna Erawati ${ }^{1}$ \\ Institut Agama Islam Negeri (IAIN) Salatiga
}

\begin{abstract}
The mastery of Arabic language is fundamental for students of Islamic Higher Education. But, generally student's score on Arabic test did not support this expectation. Some students reported that they felt inconvenient and insecure on Arabic lesson also with the lecturer. Even though, positive relationship between lecturer and students was important for creating and also keeping student's motivation in studying Arabic. This study aimed to analyze of rapport building between lecturer and students in classroom context. There were three questions, what kinds of strategy lecturers were applied to build and maintain rapport with students, which factors determine the building of rapport between lecturer and students, and how to describe the mechanism of rapport building between lecturer and student? Using qualitative approach, this study collected data from students and lecturers by questionnaire, observation, and interview. There were nine strategies used by lecturers to build rapport with students. The study found six factors determine the quality of lecturer and students' rapport.
\end{abstract}

Keywords: Arabic lesson; rapport; classroom context

\begin{abstract}
Abstrak: Penguasaan Bahasa Arab penting bagi calon sarjana dari Perguruan Tinggi Keagamaan Islam. Tetapi, skor tes mereka tidak mendukung harapan ini. Sebagian mahasiswa melaporkan mereka kurang percaya diri, nyaman, dan aman saat mengikuti kuliah Bahasa Arab maupun dalam interaksi dengan dosen pengampu. Padahal perasaan aman dan nyaman tersebut bermanfaat untuk memelihara dan meningkatkan motivasi belajar mahasiswa. Riset ini bertujuan untuk menganalisis pembentukan rapport antara dosen dengan mahasiswa dalam konteks pembelajaran di kelas. Pertanyaan penelitian meliputi, apa sajakah strategi dosen yang diterapkan untuk membentuk rapport, faktorfaktor apa saja yang memengaruhi pembentukan rapport, dan bagaimana mekanisme terbentuknya rapport antara dosen dengan mahasiswa? Studi ini menggunakan pendekatan kualitatif, di mana data dikumpulkan melalui teknik kuesioner, observasi, dan interviu. Ada sembilan strategi pembentukan rapport yang ditemukan. Terdapat enam faktor yang memengaruhi pembentukan rapport dosen-mahasiswa.
\end{abstract}

Kata kunci: Bahasa Arab; rapport; konteks kelas

Dalam kurikulum Pendidikan Perguruan Tinggi Keagamaan Islam Negeri di Indonesia, penguasaan Bahasa Arab menempati posisi penting. Masing-masing Pendidikan

Korespondensi mengenai isi artikel ini dapat dilakukan melalui email: ${ }^{1}$ munaerawati@gmail.com

PSIKOHUMANIORA: Jurnal Penelitian Psikologi — I SSN: 2502-9363 (p); 2527-7456 (e) 


\section{Muna Erawati}

Perguruan Tinggi Keagamaan Islam (PTKI) berinovasi meningkatkan kompetensi Bahasa Arab mahasiswa. Salah satu PTKI, misalnya menambahkan pembelajaran khusus selama satu tahun bagi mahasiswa baru untuk semua fakultas.

Bagi para calon Guru Pendidikan Agama Islam (GPAI), penguasaan Bahasa Arab semakin penting. Berdasarkan pengamatan selama menjadi Dosen Pembimbing Lapangan dalam Praktik Pengalaman Lapangan bagi calon GPAI, praktikan seringkali berhadapan dengan pertanyaan siswa tentang peristilahan Bahasa Arab. Bagi praktikan yang cukup menguasai Bahasa Arab, permasalahan ini dapat diatasi, tetapi sebaliknya bagi praktikan yang kurang menguasai kondisi ini menurunkan kepercayaan dirinya.

Kegagapan para calon GPAI juga sering sekali muncul dalam sidang-sidang skripsi (munaqosyah). Penguji sidang seringkali menguji kompetensi Bahasa Arab mahasiswa melalui ayat-ayat al-Qur'an, Hadits Nabi, atau kata-kata bijak berbahasa Arab yang dikutip mahasiswa. Kedua fenomena di atas, mengindikasikan bahwa secara umum kompetensi Bahasa Arab para calon GPAI masih lemah.

Krasen dan Baradja (dalam Indrariani, 2010) menyatakan bahwa pengembangan kompetensi bahasa dapat diraih melalui dua cara yaitu pemerolehan (acquisition), dan belajar (learning). Pemerolehan bahasa merupakan kompetensi yang terbentuk secara alamiah, tanpa disadari -- serupa dengan kemampuan anak kecil dalam menguasai bahasa ibu atau bahasa pertama. Kompetensi bahasa yang dikuasai melalui belajar bersifat formal, dan disadari. Penguasaan bahasa selain bahasa ibu (mother tongue), sebagian besar terjadi melalui proses kedua.

Di salah satu PTKIN, perbandingan jumlah mahasiswa Program Studi Pendidikan dengan mahasiswa Program Studi Bahasa Inggris diketahui 191:743 atau 2:7. Hal ini menunjukkan bahwa animo mempelajari memang cenderung lebih rendah dibandingkan Bahasa Inggris, bahkan di PTKI yang identik dengan studi keislaman.

Ketika dilakukan wawancara pada sebagian mahasiswa dari angkatan yang berbedabeda, terungkap beberapa faktor penyebab. Pertama, adanya mental block, "Bahasa Arab itu sulit". Mental block merupakan suatu pikiran negatif yang kuat dalam jiwa seseorang. Kedua, kemalasan atau keengganan berlatih atau mengulang-ulang materi. Ketiga, label negatif pada guru atau dosen yang galak, kaku, dan kurang akrab dengan peserta didik. Keempat, metode pembelajaran yang kurang variatif. Kelima, pembiasaan yang masih minim di lingkungan kampus, dan lingkungan umum secara luas. Keenam, masih terbatasnya 


\section{Pembentukan Rapport di Kelas: Analisis Psikologis}

ketersediaan sumber pustaka maupun bacaan ringan-menghibur-informatif seperti koran, cerpen, novel, maupun buku-buku populer dalam Bahasa Arab. Ketujuh, tampilan bukubuku teks Bahasa Arab kurang menarik. Kedelapan, nilai kegunaan praktisnya dianggap rendah.

Dalam pidato pengukuhannya sebagai guru besar dalam bidang pembelajaran pada Fakultas Sastra Universitas Malang, Ainin (2011) menegaskan bahwa fenomena di atas mengindikasikan adanya demotivasi dalam pembelajaran Bahasa Arab. Demotivasi ini justru seringkali bersumber dari sosok sang pengajar. Sikap dan tindakan pengajar yang kontraproduktif dalam pembelajaran amat merugikan, karena memicu penurunan minat belajar.

Idealnya, seorang pengajar diharapkan mampu mengajar dengan pendekatan yang humanis. Pendekatan ini menjadi dasar pembentukan rapport positif dengan mahasiswa, sehingga suasana perkuliahan lebih menyenangkan. Dengan kondisi demikian, maka materi perkuliahan dapat diserap mahasiswa lebih efektif.

Menurut Zukhaira dan Kuswardono (2012) mata kuliah yang berkaitan dengan peningkatan keterampilan berbahasa Arab meliputi: istima' (menyimak), ta'bir syafawi (berbicara), qira'ah (membaca), dan ta'bir tahriri (menulis). Secara prinsipil empat komponen ini menjadi dasar kompetensi yang harus diberikan pada mahasiswa.

Ada dua sumber kendala ditinjau dari pelaku yaitu dosen dan mahasiswa. Kendala pada dosen meliputi kompetensi paedagogik dan personal yang masih dinilai kurang (Zukhaira \& Kuswardono, 2010). Sedangkan kendala pada mahasiswa bersumber dari rendahnya motivasi dan minat belajar sehingga mengakibatkan produktivitas dan prestasi akademik yang masih dianggap lemah (Nurhidayati, 2002; Hakim, 2012).

Becton (1974: 10) menyatakan rapport adalah hubungan interpersonal yang harmonis dan memuaskan. Sementara itu, Haynes dan Backwell (2010) menyatakan bahwa rapport artinya hubungan yang baik. Dalam seting klinis, hubungan yang terjalin baik antara psikolog dengan klien maupun dokter dengan pasien disebut sebagai rapport profesional (professional rapport). Rapport profesional adalah hubungan terapeutik yang didasarkan atas kepercayaan dan kerjasama serta dicapai melalui saling kesepahaman terhadap sudut pandang klien atau pasien.

Istilah positive rapport mengindikasikan hubungan yang baik berdampak positif bagi relasi pengajar dengan peserta didik. Sebagai seorang pengajar, salah satu tujuan penting 


\section{Muna Erawati}

membina rapport adalah untuk menciptakan atmosfer kelas di mana para peserta didik merasa nyaman dan berminat untuk belajar. Apabila positive rapport terbentuk maka tugas dan peran guru dapat diterima oleh peserta didik dan mereka siap mengikuti aktivitas dan petunjuk dari pengajar.

Rapport dalam pembelajaran bahasa asing berperan sebagai fondasi bagi proses pembelajaran yang konstruktif, aktif, kooperatif, dan menyenangkan di kelas. Dosen membutuhkan kerjasama dengan murid agar tujuan pembelajaran tercapai. Sementara mahasiswa berkeinginan dapat memperoleh pengalaman belajar yang kaya (riched) dan membangkitkan minat. Dengan demikian manfaat rapport antara dosen dengan mahasiswa adalah efektivitas pembelajaran dan peningkatan prestasi akademik pada peserta didik (Fleming, 2003).

Keberhasilan relasi didik tergantung pada partisipasi kedua belah pihak. Meskipun, tanggung jawab tidak selalu dapat dibagi sama rata, tetapi hubungan ini tidak dapat berjalan baik jika hanya salah satu pihak yang aktif. Artinya rapport dapat terbentuk dan berdampak pada pembelajaran di kelas jika mahasiswa juga turut ambil bagian dalam proses tersebut (Grahe \& Sherman, 2007). Dengan kata lain, rapport sangat strategis digunakan sebagai ukuran kualitas dan efektivitas hubungan didik dalam pembelajaran. Sementara itu Gurland dan Grolnick $(2003 ; 2008)$ menyatakan salah satu bentuk perilaku dosen yang stimulasi berpengaruh terhadap terbentuknya rapport adalah dukungan suportif (autonomy supportive).

Karakteristik kelas yang memiliki positive rapport dengan dosen (Haynes \& Backwell, 2010): Pertama, adanya atmosfer positif dan suportif. Setiap anggota kelas mempunyai citra diri positif yang didukung oleh kelas, sehingga mereka merasa cukup aman untuk mengekspresikan individualitasnya. Kedua, mahasiswa merasa bahagia berinteraksi dengan semua teman dan tidak akan terkotak-kotak dalam kelompok-kelompok. Ketiga, kelas menjadi mandiri, bertanggung jawab dan dapat mengatasi masalah tanpa bantuan dosen. Keempat, masing-masing mahasiswa saling percaya satu sama lain. Kelima, mahasiswa dapat berempati satu sama lain dan memahami sudut pandang teman meskipun tidak diungkapkan secara verbal. Keenam, kelas menjadi sangat menyenangkan. Ketujuh, mahasiswa memiliki sikap positif terhadap dirinya sendiri sebagai pembelajar, terhadap bahasa, dan budaya yang dipelajari. Kriteria-kriteria di muka merupakan indikatorindikator terbentuknya positive rapport di kelas. Kondisi ini dapat tercapai jika pengajar memiliki keterampilan melakukan inisiasi rapport. 


\section{Pembentukan Rapport di Kelas: Analisis Psikologis}

Dalam penelitian yang dilakukan Grahe dan Sherman (2007: 453-475) rapport diukur dengan dua indikator perilaku yaitu perilaku objektif (objective behavior) dan perilaku subjektif (subjective behavior). Perilaku objektif adalah perilaku yang tampak oleh orang lain dan dirating sama oleh orang lain. Contoh perilaku objektif antara lain adalah tersenyum, tertawa, mengangguk-angguk, menggeleng, menoleh, dan seterusnya. Perilaku subjektif adalah perilaku yang bersumber dari konstruk psikologis yang abstrak, namun bisa dimengerti walaupun tidak dimunculkan dalam perilaku spesifik. Contoh perilaku subjektif adalah rasa saling percaya, saling memperhatikan, dan memahami orang lain.

Susetyo (2004) mengatakan bahwa beberapa aktivitas mengajar yang berkaitan dengan pendekatan mengajar yang humanis adalah memberi pengalaman sukses kepada mahasiswa; mengakui, menghargai dan menerima siswa apa adanya, tidak membodohbodohkan mahasiswa, terbuka menerima pendapat dan pandangan mahasiswa tanpa menilai atau mencela, terbuka untuk komunikasi dengan mahasiswa, dan tidak hanya menghargai potensi akademik. Untuk aktivitas-aktivitas kreatif dosen tidak banyak memberikan aturan, memberi keamanan psikologis, menceritakan pengalaman, menulis cerita, menghargai usaha, imaginasi, fantasi dan inovasi siswa, stimulasi banyak buku bacaan, dan memberikan aktivitas brainstorming. Dengan demikian, perilaku di atas merupakan indikator perilaku dosen yang membangun rapport.

Eksperimen Sharpley, Fairnie, Tabary-Collins, Bates, dan Lee (2000) menemukan tiga bentuk respon verbal yang paling penting dalam pembentukan rapport saat mengamati aktivitas konselor dengan klien dalam seting klinis. Tiga bentuk respon verbal tersebut adalah dorongan minimal (minimal encouragers), merefleksikan perasaan (reflections of feeling), dan mengulang kembali ucapan klien (restatements). Skoring rapport dikategorikan menjadi lima yaitu sangat lambat, lambat, sedang, cepat, dan sangat cepat terbentuk rapport antara konselor dengan klien.

Beberapa penelitian menunjukkan bahwa kedekatan dosen dengan mahasiswa berpengaruh terhadap motivasi belajar dan prestasi akademik (Cesar \& Santos 2006; Jannah, 2009; Kurniawati, 2011). Rapport positif dosen dengan mahasiswa juga berperan dalam mengembangkan sosialisasi (interaksi) antar mahasiswa, dan perkembangan afektif (Cesar \& Santos 2006).

Untuk itu perlu dilakukan kajian mengenai pembentukan rapport dosen dengan mahasiswa dalam pembelajaran Bahasa Arab. Kajian ini diharapkan dapat menjawab tiga pertanyaan. Pertama, bagaimana strategi dosen dalam membangun rapport dengan 


\section{Muna Erawati}

mahasiswa? Kedua, apa saja determinan-determinan yang berperan dalam pembentukan rapport dosen dengan mahasiswa? Ketiga, bagaimana dinamika psikologis terciptanya rapport dosen dengan mahasiswa?

\section{Metode}

Penelitian ini menggunakan seting kehidupan perguruan tinggi khususnya interaksi di kelas sebagai kancah penelitian. Pertanyaan penelitian akan dijawab menggunakan pendekatan kualitatif. Data yang terkumpul dapat berupa narasi, catatan lapangan, dokumen, foto, maupun angka. Meskipun melibatkan penggalian data dengan teknik kuesioner, data yang dikumpulkan akan diolah menggunakan teknik analisis kualitatif. Jenis penelitian ini adalah penelitian kualitatif fenomenologis.

Penelitian ini dilakukan pada sebuah kampus perguruan tinggi keagamaan di salah satu kota di Jawa Tengah. Sesuai dengan ruang lingkup kajian, maka populasi meliputi dosen pengampu dan mahasiswa PAI peserta mata kuliah Bahasa Arab. Informan yang berstatus dosen pengampu diamati ketika mengajar di kelas, kemudian ditindak lanjuti dengan wawancara. Peserta mata kuliah yang dilibatkan dalam penelitian ini adalah mahasiswa Prodi PAI yang kelasnya ditentukan secara acak. Ada dua dari tujuh kelas yang digunakan sebagai sampel.

Informan yang dilibatkan dalam penelitian adalah dosen pengampu berjumlah tujuh orang yang terdiri dari empat dosen tetap dan tiga dosen tidak tetap. Data yang diungkap dari dosen yaitu hal-hal yang terkait dengan pembentukan rapport dengan mahasiswa. Observasi dilakukan pada lima kelas dengan lima dosen berbeda, sedang wawancara dilaksanakan pada empat dosen. Selain itu, informan yang kedua adalah mahasiswa semester dua Prodi PAI sebanyak dua kelas (70 orang). Mereka diminta melaporkan atmosfer di kelas yang mereka rasakan setelah menjalani perkuliahan Bahasa Arab.

Data yang digunakan dalam penelitian ini diambil pada tahun akademik 2014/2015. Beberapa teknik pengumpul data digunakan untuk mengungkap hal berbeda. Berikut ini uraian teknik dan jenis data yang akan dikumpulkan meliputi dokumentasi untuk mengumpulkan data terkait dengan personalia, jadwal perkuliahan, daftar hadir, dan jurnal mengajar. Kedua, observasi digunakan untuk melihat interaksi dosen mahasiswa dalam seting di dalam ruang kelas. Ketiga, wawancara dilakukan pada dosen untuk mengeksplorasi gagasan dan pengalaman terkait dengan hubungan dosen dan mahasiswa di kelas. Keempat, kuesioner digunakan untuk mengungkap atmosfer kelas yang dilaporkan oleh mahasiswa. 


\section{Pembentukan Rapport di Kelas: Analisis Psikologis}

Instrumen untuk wawancara, observasi, dan kuesioner untuk mengungkap jalinan rapport akan dikembangkan dari perilaku humanis guru yang dikemukakan oleh (Susetyo, 2004). Penggunaan teknik berbeda untuk mengungkap indikator yang sama, dimaksudkan untuk saling melengkapi dan mengecek kesahihan data (triangulasi).

Untuk melakukan identifikasi kondisi atmosfer kelas akan diungkap dengan indikator yang dikembangkan dari Haynes dan Backwell (2010) tentang karakteristik kelas yang memiliki positive rapport. Kisi-kisi kuesioner yang digunakan mengungkap atmosfer kelas meliputi mahasiswa merasa aman mengekspresikan individualitasnya, mahasiswa merasa senang berinteraksi dengan teman, mahasiswa merasa percaya satu sama lain, mahasiswa dapat berempati dan memahami sudut pandang teman, memiliki sikap positif terhadap diri sendiri, bahasa dan budaya Arab, kelas menjadi lebih mandiri, bertanggung jawab, dan dapat mengatasi masalah bersama-sama, suasana kelas menjadi sangat menyenangkan. Kuesioner terdiri dari 37 item pernyataan dengan pilihan jawaban hampir selalu (HS), sering (S), cukup sering (CS), pernah (P), dan tidak pernah sama sekali (TP). Skoring item yang semua favorabel dimulai dari angka 0 untuk pilihan TP sampai 4 untuk pilihan HS.

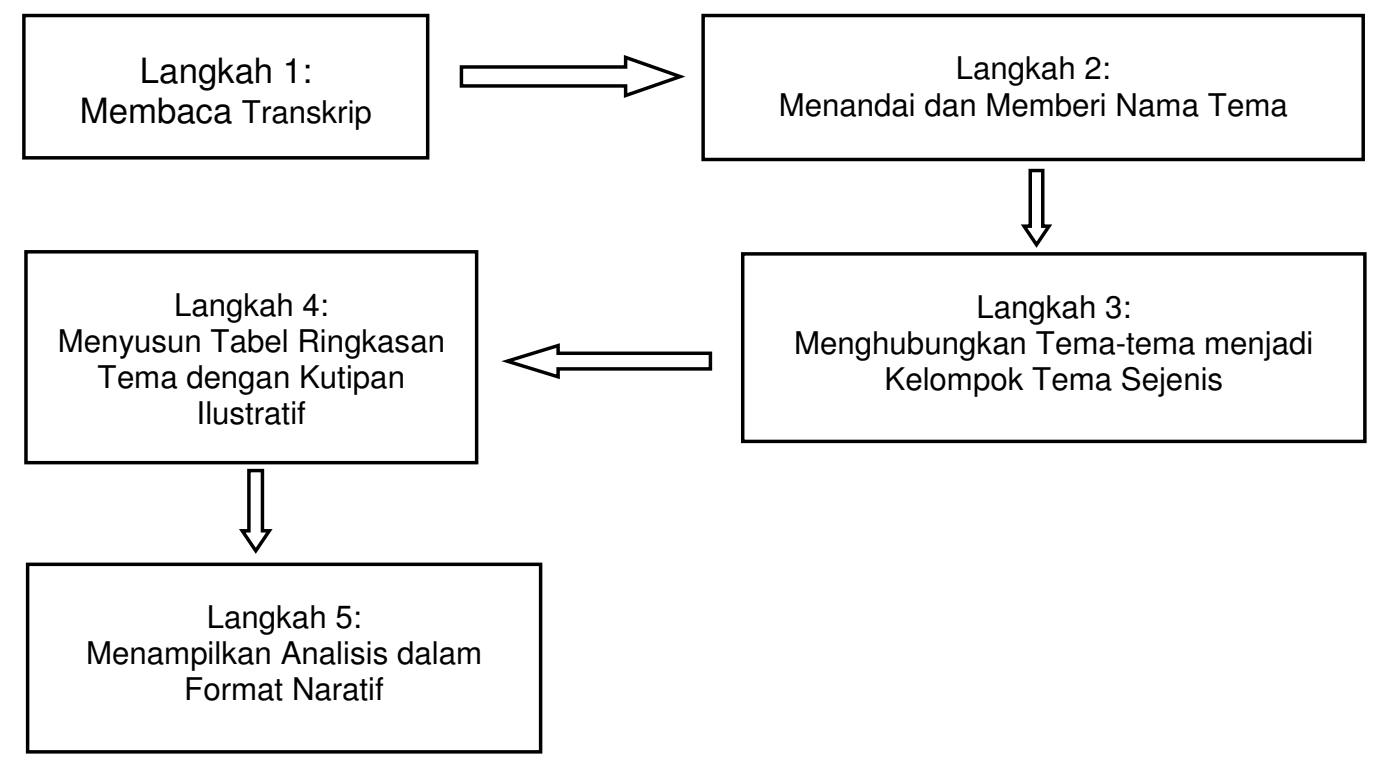

Gambar 1. Tahap-tahap analisis menurut Smith dan Eatough (dalam Lyons \& Coyle, 2007:35-50).

Data angka akan dianalisis dengan teknik statistik deskriptif. Kedudukan data angka adalah sebagai pelengkap (sekunder). Data naratif sebagai data utama akan dianalisis dengan metode kualitatif dimana data yang terhimpun dikoding, diorganisir, kemudian 


\section{Muna Erawati}

direduksi menjadi tema-tema (Poerwandari, 1998). Dalam penelitian fenomenologis, teknik analisis diadopsi dari Smith dan Eatough (dalam Lyons \& Coyle, 2007) yang disebut IPA (Interpretative Phenomenological Analysis). Langkah-langkah analisis melalui tahapan dapat digambarkan pada gambar 1.

\section{Hasil}

Profil dosen. Pengajar Bahasa Arab pada waktu penelitian berlangsung terdiri dari 19 dosen tetap dan 28 pengajar tidak. Sebaran pengajar dapat disimak pada Tabel 1:

Tabel 1.

Sebaran pengajar

\begin{tabular}{llll}
\hline \multicolumn{1}{c}{ Status Dosen } & Jumlah dan Persentase & Jenis Kelamin & \multicolumn{1}{c}{ Jumlah } \\
\hline Dosen Tetap & $19(40.43 \%)$ & Perempuan & $2(4.26 \%)$ \\
& & Laki-laki & $17(36.17 \%)$ \\
Dosen Tidak Tetap & $28(59.57 \%)$ & Perempuan & $4(8.51 \%)$ \\
& & Laki-laki & $24(51.06 \%)$ \\
\hline \multicolumn{1}{c}{ Jumlah } & $\mathbf{4 7 ( 1 0 0 \% )}$ & & $\mathbf{4 7}(\mathbf{1 0 0} \%)$ \\
\hline
\end{tabular}

Mata kuliah semester satu tercatat dalam kurikulum sebagai Bahasa Arab I dan semester dua sebagai Bahasa Arab II. Masing-masing mata kuliah ini bermuatan 4 SKS. Setiap semester ada dua hari dialokasikan untuk pembelajaran yaitu Senin dan Selasa. Kegiatan belajar dimulai pada pukul 07.00 dan berakhir pada 10.20 WIB. Dalam pertemuan hari Senin dan Selasa mahasiswa mempelajari sub materi yang berbeda. Umumnya dosen membagi perkuliahan menjadi dua sesi, sesi pertama jam $07.00 \mathrm{~s} / \mathrm{d}$ 08.50, diselingi 10 menit istirahat. Pukul 09.00 s/d 10.20 berlangsung sesi berikutnya.

Setiap mahasiswa ditempatkan dalam kelas bertingkat setelah mereka menjalani tes penempatan (placement test). Penamaan kelas didasarkan atas ruang di mana pembelajaran berlangsung, di mana kelas bertingkat dari tertinggi di ruang A1, A2, A3, dan seterusnya. Materi kuliah disajikan dalam modul. Pengelola membagikan modul dan kamus karya Mahmud Yunus pada setiap mahasiswa.

Gambaran skor dan Bahasa Inggris dengan menggunakan data dokumentasi. Ketika dilakukan penghitungan rerata prestasi belajar dibandingkan Bahasa Inggris dari sampel 32 calon GPAI, diketahui bahwa diperoleh rerata skor Bahasa Arab I adalah 2,59 ( $\mathrm{SD}=0,66)$; rerata skor Bahasa Inggris I adalah 3,00 (SD=0,45). Rerata skor Bahasa Arab II adalah 2,73 $(\mathrm{SD}=0,72)$; dan rerata skor Bahasa Inggris II adalah 3,1 $(\mathrm{SD}=0,52)$. Ketika dilakukan 


\section{Pembentukan Rapport di Kelas: Analisis Psikologis}

pengujian selanjutnya, tidak ditemukan perbedaan signifikan antara rerata nilai Bahasa Arab I dengan Bahasa Arab II, serta rerata nilai Bahasa Inggris I dan Bahasa Inggris II. Sementara itu, ditemukan perbedaan bermakna antara rerata nilai Bahasa Arab I dengan Bahasa Inggris I $(t=-4,27 ; p=0,00)$, serta rerata nilai Bahasa Arab II dengan Bahasa Inggris II $(\mathrm{t}=-2,63 ; \mathrm{p}=0,01)$. Paparan di muka mengindikasikan bahwa kompetensi Bahasa Arab mahasiswa lebih rendah daripada kompetensi Bahasa Inggris.

Atmosfer kelas. Atmosfer kelas secara keseluruhan menunjukkan skor hipotetik rerata 74, skor minimum 0, dan skor maksimal 148. Rerata empirik atmosfer kelas adalah 96 dengan skor minimum 33 dan skor maksimal 129. Rerata skor atmosfer kelas berada di atas rerata hipotetik. Separuh responden $(50 \%)$ menilai atmosfer di kelas kondusif. Hal ini tampak pada interval $93 \mathrm{~s} / \mathrm{d} 111$ yang frekuensinya mencapai 35 responden. Responden sejumlah 21,5\% menganggap cukup kondusif, 17\% menyatakan sangat kondusif, $10 \%$ kurang kondusif, dan 1,5\% mengklaim tidak kondusif. Dengan demikian, atmosfer kelas secara umum dinilai kondusif oleh mahasiswa.

Sebagian besar mahasiswa merasa cukup aman (52,86\%) mengekspresikan individualitasnya di kelas, 41,42\% merasa kurang bisa aman, dan hanya sedikit (5,72\%) yang merasa benar-benar aman dalam mengekspresikan individualitasnya.

Dua kelompok mahasiswa sebesar 47,14\% sama-sama merasa cukup senang dan senang berinteraksi dengan teman di kelas pembelajaran Bahasa Arab. Hanya sedikit $(5,72 \%)$ yang merasa kurang senang berinteraksi dengan teman sekelas dalam perkuliahan. Sebagian besar mahasiswa $(61,43 \%)$ bisa saling percaya antar teman di kelas. Sebagian lain (20\%) kurang bisa percaya, dan 18,5\% justru merasa antar peserta bisa saling percaya satu sama lain.

Umumnya (58,57\%) mahasiswa merasa cukup bisa mengembangkan sikap empati dan memahami sudut pandang teman dalam satu kelas. Sebanyak 28,57\% mahasiswa melaporkan benar-benar dapat mengembangkan sikap empatis dan memahami sudut pandang teman, sedangkan $12,86 \%$ menilai kurang. Sikap positif terhadap diri sendiri, bahasa dan budaya Arab. Sebanyak 48,87\% mahasiswa menilai cukup positif terhadap diri sendiri-bahasa-budaya Arab. Persentase ini hampir setara dengan mereka yang menilai positif (42,86\%), dan 8,57\% memandang kurang positif.

Mayoritas menilai kelas menjadi cukup mandiri, cukup bertanggung jawab, dan cukup dapat mengatasi masalah bersama-sama (55,71\%). Sebagian menganggap kurang $(24,29 \%)$, dan $20 \%$ menilai benar-benar dapat mandiri, tanggung jawab, dan mengatasi 


\section{Muna Erawati}

masalah bersama. Selama pembelajaran, mahasiswa dari dua program studi dan kelas yang berbeda-beda berinteraksi di satu kelas yang sama. Setelah mengikuti kegiatan selama dua semester, sebanyak 51,42\% menyatakan suasana kelas menjadi cukup menyenangkan, $34,29 \%$ tegas menyatakan menyenangkan, dan $14,29 \%$ menyatakan kurang menyenangkan.

\section{Diskusi}

Strategi pembentukan rapport. Dosen yang berpartisipasi dalam penelitian ini melaporkan tidak ada komunikasi interpersonal dengan mahasiswa di luar kelas (catatan lapangan dari observasi). Komunikasi interpersonal di dalam kelas relatif cukup baik. Jumlah mahasiswa yang secara spontan bertanya masih dapat dihitung dengan jari.

Pengamatan dan interviu yang telah dilaksanakan memberi bukti-bukti adanya upaya-upaya dari dosen untuk membina rapport atau hubungan baik antara dosen dengan mahasiswa. Semua dosen yang terlibat memiliki pemahaman yang sama bahwa hubungan baik ini perlu diciptakan dalam pembelajaran. Lebih khusus lagi, di kelas yang memiliki kemampuan lebih rendah.

Mahasiswa yang berasal dari sekolah umum atau yang tidak memiliki latar belakang pendidikan pesantren umumnya duduk di kelas tetap (kelas berkompetensi rendah). Kondisi ini diperparah lagi dengan minimnya pendidikan agama yang dimiliki. Mereka ditemukan dalam keadaan kurang atau bahkan sama sekali tidak mampu membaca dan menulis al-Qur'an. Sebagaimana diketahui, dua kemampuan ini menjadi modal dasar untuk mempelajari materi-materi tata bahasa Arab.

Tujuan pembelajaran adalah agar peserta didik dapat mempelajari al-Qur'an, Kitabkitab Hadis, karya ilmiah dengan lancar, serta melakukan percakapan sederhana dalam Bahasa Arab. Untuk mengatasi kendala baca tulis al-Qur'an (BTA), mahasiswa dilaksanakan pretes (screening). Bagi mahasiswa yang belum atau tidak lancar BTA diwajibkan mengikuti asistensi BTA dan praktek ibadah. Upaya ini perlu disambut baik, dan perlu dimonitoring efeknya terhadap peningkatan kompetensi BTA dan praktek ibadah mahasiswa.

Dosen senior umumnya ditempatkan di kelas-kelas yang sudah familiar dengan Bahasa Arab. Harapannya agar mahasiswa memperoleh pengalaman dan pengetahuan kebahasaan yang semakin meningkat. Sementara itu, kelas dengan kompetensi lebih rendah diajar dosen-dosen muda. Umumnya mereka berstatus dosen tidak tetap. Alasan kebijakan ini agar kelas tersebut mendapat dosen yang memiliki energi dan strategi yang lebih jitu dalam menguasai Bahasa Arab. 


\section{Pembentukan Rapport di Kelas: Analisis Psikologis}

Beberapa strategi yang digunakan dosen untuk membina hubungan baik dengan mahasiswa di kelas: Pertama, menghadirkan diri ke hadapan mahasiswa. Pertemuan pertama merupakan momentum penting untuk memberi kesan tertentu pada mahasiswa. Umumnya hal-hal yang dilakukan dosen Bahasa Arab adalah memperkenalkan diri siapa nama dan latar belakang pendidikan yang dimiliki.

Kedua, membuka diri dengan cara menceritakan pengalaman-pengalaman pribadi, keluarga, atau kehidupan yang terkait dengan dirinya pada mahasiswa. Umumnya dosen menceritakan tentang pengalaman belajar, alasan menyukai, strategi menguasai, dan prestasi dalam bidang Bahasa Arab. Kehidupan keluarga yang diceritakan umumnya adalah prestasi anggota keluarga dan latar belakang ekonomi keluarga. Berikut salah satu contoh petikan cerita dosen:

Kuliah di sini SPP-nya termurah di dunia. Anak saya kuliah di PTN SPP-nya 10 juta. Kampus sini 700 ribu. Siapa yang nilai ujian nasionalnya 10? Anak saya fisika dan kimia 10, malah Bahasa Indonesia jelek sendiri... 8 (Observasi kelas Pak Alif).

Ketiga, mengungkapkan sisi-sisi manusiawi. Dosen mengungkapkan kegagalan, kekeliruan, dan kelemahan di masa lalu, namun sekaligus menekankan pentingnya membangun semangat untuk memperbaiki kegagalan. Keempat, menunjukkan bahwa dosen ingin mengenal mahasiswa baik nama, latar belakang pendidikan, dan alamat tinggalnya. Semua dosen menyadari pentingnya menghafal nama mahasiswa. Walaupun hal ini tidak selalu dapat dilakukan dengan baik, tetapi setidaknya ada beberapa nama mahasiswa yang tertanam dalam memorinya. Dengan memanggil namanya, mahasiswa dapat merasakan bahwa diri mereka diperhatikan sang dosen.

Keempat, gestur atau gerak-gerik tubuh dan ekspresi wajah dosen. Gerakan yang pelan, gerakan mendekat ke mahasiswa, menatap wajah mahasiswa, tersenyum, tatapan mata lunak, duduk santai di depan mahasiswa, dan sebagainya mencirikan ajakan untuk membangun hubungan baik. Ekspresi wajah dosen umumnya netral, beberapa dosen menampilkan senyum sepanjang pembelajaran. Keenam, mengajak dialog mahasiswa. Dosen mencoba membangun percakapan dengan seluruh kelas mengenai hal ringan dan percakapan interpersonal dengan satu persatu mahasiswa.

Kelima, menunjukkan kepedulian pada mahasiswa. Kepedulian ditunjukkan dengan ucapan verbal seperti komentar, nasihat, atau saran. Berikut contoh nasihat atau saran dosen:

Kalau tinggal di kost mungkin saat tidur enak, dibangunkan mereka bisa mengelak. Tetapi kalau di pondok, ya harus bangun. Lingkungan kan amat penting membentuk kebiasaan 


\section{Muna Erawati}

mahasiswa, berbeda dengan tinggal di rumah atau kost. Makanya Saya menyarankan pada mahasiswa untuk mondok saja daripada kost (Wawancara dengan Pak Barakah).

Keenam, memecah kebekuan dengan humor. Berikut contoh humor yang dilontarkan Pak Salas, "Orang-orang korban kambing, sapi, paling kalau kalian, korban perasaan...." "Pemerintah Arab Saudi melarang pejabat Indonesia melempar jumrah, karena sesama setan dilarang saling melempar batu...".

Ketujuh, menaruh kepercayaan pada mahasiswa. Dosen umumnya menyatakan bahwa mereka yakin bahwa mahasiswa dapat melakukan sesuai dengan yang diharapkan. Kesepuluh, memberi pengukuhan dalam bentuk ucapan pujian maupun hadiah uang apabila mahasiswa melaksanakan tugas dari dosen.

Berdasar hasil pengamatan dan wawancara, muncul beberapa bukti sikap, ucapan, dan perilaku dosen yang kurang membangun rapport positif dengan mahasiswa. Pertama, sikap negativisme. Kedua, bentakan. Ketiga, ancaman untuk menghukum. Berikut ungkapan yang kontraproduktif:

"Jadi mahasiswa boleh bertanya, tapi dilarang menguji dosen. Itu dosa besar menguji dosen. Saya pernah ditanya mahasiswa, tetapi dia hanya ingin menguji. "Jangan sekali-kali menguji dosen, nguji dosen itu dosa besar, masuk neraka". "... kalau minggu depan (tertuju kembali pada mahasiswa putera yang duduk di kelompok puteri) masih duduk di situ, akan saya hukum...la yamuutu wala yahya ... ora mutu ora duwe biaya haha ... (Observasi di kelas Pak Alif)".

Paparan di muka dikaji dari sisi kemungkinan dampak negatif bagi mahasiswa. Dosen pada dasarnya bermaksud baik dan memancing humor, akan tetapi strategi penyampaian tersebut justru dapat menimbulkan keengganan mahasiswa berpartisipasi aktif di kelas. Sementara itu, dalam observasi di kelas Pak Alif diketahui bahwa beliau memiliki withitness yang paling tinggi. Withitness adalah kemampuan dosen untuk memonitor hal-hal apa saja yang terjadi dalam kelas. Kemampuan memonitor dapat efektif apabila diikuti dengan cara-cara yang santun dalam menegur mahasiswa. Sebaliknya, teguran yang kasar atau kurang proporsional dapat menimbulkan dampak negatif seperti penarikan diri mahasiswa dari partisipasi di kelas.

Tanda-tanda suasana kelas positif yang diperoleh dari pengamatan adalah pertama, mahasiswa merasa nyaman mengikuti pelajaran. Hal ini tampak dari duduk yang santai tetapi tetap sopan, dapat menikmati humor dan cerita dosen, dan bertahan mengikuti pembelajaran sampai selesai. Kedua, persentase kehadiran mahasiswa. Di kelas yang ikatan dosen dengan mahasiswa lebih kuat, maka jarang ditemukan mahasiswa absen. Sebaliknya 
pada kelas yang ikatan dengan dosen kurang kuat, absensi lebih sering dijumpai. Ketiga, dapat dengan spontan mengekspresikan pertanyaan. Pertanyaan dapat bersifat serius maupun pertanyaan yang ringan. Keempat, bersedia berpartisipasi dalam aktivitas di kelas. Partisipasi terlihat dari 'mengangkat tangan' untuk menjawab pertanyaan, mencoba mengerjakan tugas dosen, dan sebagainya. Kelima, ada inisiatif untuk memecahkan permasalahan di kelas. Hal ini tampak dari gagasan untuk menanyakan hal-hal terkait dengan kebutuhan kelas seperti pengambilan modul, mengecek kehadiran dosen, dan sebagainya.

Perbedaan cara mengajar dijumpai pada beberapa aspek yaitu: Pertama, cara menampilkan diri di depan mahasiswa. Kedua, aturan main dalam perkuliahan. Sebaliknya tidak ditemukan dosen yang mengemukakan kontrak belajar. Ketiga, cara memperlakukan mahasiswa. Keempat, suasana yang dibangun di kelas. Kelima, keluasan dalam pengayaan materi kuliah. Unsur-unsur perbedaan ini diasumsikan sebagai gaya khusus yang erat kaitannya dengan faktor perbedaan pengalaman mengajar, nilai-nilai yang diprioritaskan, karakteristik kepribadian pengajar, dan visi dalam mengajar. Keenam, cara memberi pengukuhan. Ada dosen yang memberikan pengukuhan secara verbal, ada pula yang memberi hadiah uang.

Brown (dalam Swenson, 2010) mengatakan bahwa faktor-faktor yang berperan terhadap pembentukan rapport oleh dosen adalah penguasaan materi ajar, sense of humor (jokes), kemampuan mengajar sesuai dengan kemampuan mahasiswa, dan kemauan untuk menanggapi pertanyaan mahasiswa. Granitz, et al. (dalam Swenson, 2010), mengembangkan model rapport di mana faktor yang memengaruhi rapport yaitu pendekatan, kepribadian, dan homophily (memiliki perasaan sama). Homophily itu sendiri oleh Lazarsfeld dan Merton (dalam Golub \& Jackson, 2012) mengacu pada kecenderungan individu untuk mengaitkan diri dengan orang lain yang mirip dengannya.

Menurut Norfolk, Birdi, dan Walsh (20077) kekuatan rapport antara pengajar dengan peserta didik, psikolog dengan klien, maupun dokter dengan pasien ditentukan oleh kemampuan empati. Empati itu sendiri adalah keterampilan kognitif dalam membayangkan posisi atau kondisi orang lain yang digunakan untuk menciptakan kesepahaman yang akurat mengenai apa yang dipikirkan dan diucapkan oleh orang lain (cognitive skill of interpersonal imaginations used to establish an accurate understanding of the thoughts or words of the other). Empati dapat ditinjau dari dua sisi yaitu motivasi empati (empathic motivation) atau hasrat untuk memahami (the desire to understand), dan keterampilan empati (empathic skills) 


\section{Muna Erawati}

yaitu kemampuan untuk memahami (the ability to understand). Selain empati, keterampilan lain yang penting dalam membangun rapport adalah keterampilan dalam berkomunikasi.

Pada sisi lain, Norfolk et al . (2007) merangkum ada tiga sumber faktor yang memengaruhi pembentukan rapport yaitu pertama faktor yang bersumber dari konselor/ guru/dokter yang meliputi mood atau suasana hati, kepercayaan-kepercayaan tertentu yang diyakini (self-belief), kesadaran diri (self-awareness), dan harapan (expectation). Kedua, bersumber dari klien/murid meliputi suasana hati, kompleksitas masalah/pelajaran, kesadaran diri, dan harapan. Ketiga, sumber lingkungan meliputi atmosfer kelas, sumber daya, dan kondisi waktu. Beberapa faktor memengaruhi inisiasi pengajar untuk menjalin rapport dengan peserta didik antara lain karakteristik kepribadian dan faktor demografi seperti latar belakang pendidikan-status sosial ekonomi-jenis kelamin (Becton, 1974). Sementara Fleming (2003) mengungkapkan pengalaman mengajar, pengetahuan (wawasan), keterampilan, cara pandang terhadap profesi, cara pandang terhadap peserta didik, dan nilai-nilai yang diyakini pengajar menentukan inisiasi menjalin positive rapport.

Faktor-faktor berikut ditemukan berpengaruh terhadap pembentukan positive rapport di kelas: pertama, visi mengajar. Visi berisi pandangan jauh ke depan mengenai apa tujuantujuan terukur dari suatu program kegiatan, dalam hal ini kegiatan mengajar di kelas. Semakin dosen visioner atau memiliki tujuan terukur yang jelas dan kuat, maka semakin tinggi dedikasi dan energi yang dicurahkan untuk mendidik mahasiswa. Berdasarkan wawancara dan observasi, visi sebagian dosen tidak dapat ditangkap secara jelas.

Kedua, pandangan dosen terhadap mahasiswa. Semua informan mengungkapkan keprihatinan pada kondisi mahasiswa, tetapi cenderung menyalahkan keadaan ini sebagai salah satu penyebab ketidakpuasan mereka dengan hasil pembelajaran.

Ketiga, Energi-kemauan-kesungguhan dosen yang dicurahkan dalam mengajar. Dedikasi dan komitmen dosen yang tinggi dalam mengajar dapat menjaga stamina dan kesabaran dalam menghadapi berbagai kendala di kelas. Energi ini menggerakkan segenap jiwa dosen untuk menyusun strategi mengajar yang sesuai dengan karakteristik kelas.

Keempat, keterampilan interpersonal. Istilah keterampilan ini dimaksudkan untuk menekankan bahwa kemampuan ini sangat mungkin dipelajari. Gardner (dalam Sharifi, 2008) mengemukakan bahwa kecerdasan interpersonal terkait dengan kemampuan memahami tujuan, motif, dan perasaan orang dalam relasi sosial. Kompetensi interpersonal setidaknya meliputi kemampuan untuk memulai suatu hubungan interpersonal, kemampu- 


\section{Pembentukan Rapport di Kelas: Analisis Psikologis}

an membuka diri, kemampuan memberikan dukungan emosional kepada orang lain, kemampuan bersikap asertif, empati, serta kemampuan mengelola dan mengatasi konflik dengan orang lain. Kelima, jumlah dosen pengampu. Kelas yang diampu dosen tetap lebih positif iklimnya daripada kelas yang berganti-ganti dosen. Pergantian ini dapat mengurangi ikatan emosional antara dosen dengan mahasiswa. Keenam, kesan mahasiswa terhadap dosen. Rapport dapat terbangun dengan baik apabila upaya dosen dapat direspon secara baik oleh mahasiswa. Semakin positif kesan mahasiswa terhadap dosen, maka semakin berkemungkinan hubungan baik ini dapat berjalan dengan efektif.

Titik berat keberhasilan pembentukan rapport yang baik di kelas adalah pada diri dosen. Bagaimanapun, kewenangan serta kapabilitas dosen menjadi alasan utama. Walaupun demikian, peran mahasiswa tidak boleh diabaikan. Upaya sepihak dari dosen tanpa ada respon positif dari peserta didik menyebabkan kegagalan relasi interpersonal di kelas. Baik dosen maupun mahasiswa mengalami ketidaknyamanan serta kecurigaan. Akibatnya pembelajaran hanya berlangsung sekedar menyelesaikan silabi semata. Mengingat demikian pentingnya hubungan baik pengajar dengan peserta didik inilah maka pembelajaran di perguruan tinggi sekalipun seharusnya mengembangkan strategi untuk dapat diterapkan di kelas oleh para staf dosen.

Hubungan dosen dengan mahasiswa menjadi faktor sangat penting yang memengaruhi kesehatan emosi, motivasi, dan pembelajaran mahasiswa selama mengenyam pendidikan. Ketika mahasiswa memiliki hubungan positif dan suportif dengan dosen, mereka cenderung memiliki efikasi diri yang lebih tinggi dan motivasi intrinsik yang lebih besar untuk belajar. Mahasiswa akan lebih terlibat dalam pembelajaran dengan kata lain lebih self-regulated, terhindar dari tindakan negatif-destruktif, dan lebih meningkat prestasinya (Ormrod, 2008).

Hubungan yang terjalin baik ini tidak hanya diharapkan membawa dampak pada kenyamanan mahasiswa dalam belajar serta peningkatan prestasi belajar. Selain itu, hubungan baik tersebut juga dapat berefek pada psikologi si pengajar. Hubungan yang baik membuat rasa nyaman atau puas bagi si pengajar itu sendiri. Sebaliknya hubungan yang terjalin kurang harmonis, dapat membawa dampak negatif seperti perasaan tidak senang, tidak puas, frustrasi, tertekan baik pada diri pengajar maupun mahasiswa. Kondisi ini saling pengaruh-memengaruhi.

Gambar 2 berikut menjelaskan bahwa inisiasi rapport yang dilakukan dosen dapat membentuk positive rapport. Hubungan baik dosen dengan mahasiswa ini menyebabkan suasana kelas menjadi menyenangkan atau kondusif untuk belajar. Pihak pengajar merasa 


\section{Muna Erawati}

terus bersemangat dalam mengajar, sedangkan mahasiswa sedikit demi sedikit meningkat motivasi dan minat belajar. Hasilnya, dosen mendapatkan kepuasan dalam mengajar di kelas, sedangkan mahasiswa merasa puas dengan hasil prestasi belajarnya.

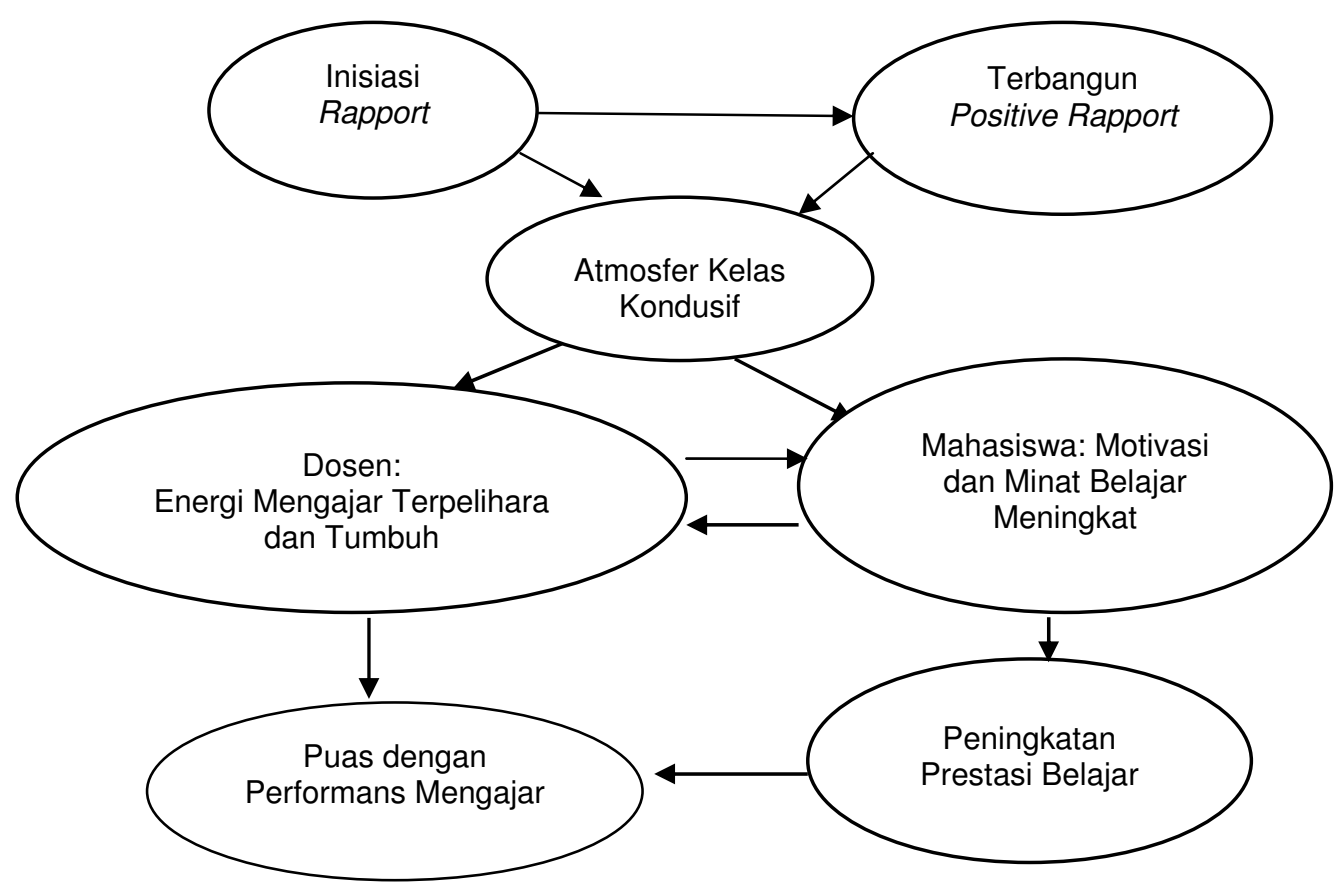

Gambar 2. Skema Dinamika Psikologi Efek Positive Rapport terhadap Dosen dan Mahasiswa.

Sebaliknya, jika inisiasi tidak dilakukan dengan baik atau tidak berhasil, maka hubungan dosen dengan mahasiswa kurang nyaman. Mahasiswa dapat saja merasa ketakutan, malas, atau menghindari pelajaran. Dosen pun bisa jadi kecewa dan frustrasi dengan mahasiswa. Akibatnya suasana kelas menjadi kurang kondusif. Dosen maupun mahasiswa sama-sama kurang termotivasi dan berminat. Dosen hanya sekedar menjalankan tugas tanpa memperdulikan kebutuhan mahasiswa. Mahasiswa merasa tidak bisa mengikuti pelajaran dengan baik dan tidak memahami perlunya mempelajari. Akhirnya, baik dosen maupun mahasiswa merasa tidak puas dengan pengalaman di kelas. Hal ini sejalan dengan survei Smith-Lovin dan Cook (dalam Swenson, 2010), rapport berdampak positif bagi mahasiswa, dosen, maupun pihak-pihak di luar kelas. Delucchi, Delucchi, dan Pelowski (dalam Swenson, 2010) menyatakan, ada hubungan antara rapport dosen-mahasiswa dengan pengajaran efektif. 


\section{Pembentukan Rapport di Kelas: Analisis Psikologis}

Menurut data atmosfer kelas yang dilaporkan mahasiswa di semester akhir, terlihat bahwa secara umum atmosfer kelas cukup kondusif. Apabila dikaitkan dengan skor mata kuliah Bahasa Arab I dan Bahasa Arab II -- dari penelusuran nilai mahasiswa tahun-tahun sebelumnya -- maka perlu dilakukan upaya meningkatkan iklim positif.

\section{Simpulan}

Kesimpulan. Beberapa temuan yang relevan dengan topik penelitian, pertama, penanaman nilai-nilai moral sudah diterapkan sebagian kelas. Teknik bercerita digunakan sebagai sarana mengirim pesan moral. Kedisiplinan waktu pada mahasiswa juga lebih terlihat di mana mereka cenderung tepat waktu dan duduk di dalam kelas meski dosen belum datang. Dalam pengamatan justru dosen yang lebih sering tidak tepat waktu tiba di kelas.

Kedua, sebagian besar dosen tidak menyampaikan kontrak belajar yang disepakati dengan mahasiswa. Beberapa dosen menyampaikan aturan main di kelas, namun hal ini bersifat kurang sistematis dan sepihak.

Ketiga, atmosfer di kelas ditemukan berada pada level kondusif. Hal ini menunjukkan bahwa upaya dosen dalam mengembangkan rapport dengan mahasiswa sudah cukup baik. Keterlibatan mahasiswa secara sukarela di kelas masih dapat dihitung dengan jari (masih kurang). Interaksi interpersonal di luar kelas baik mengenai urusan akademik maupun non akademik tidak dijumpai sama sekali antara dosen dengan mahasiswa.

Keempat, metode pembelajaran yang diterapkan dosen relatif sama yakni mengkombinasikan ceramah, tanya jawab, dan penugasan. Metode pembelajaran lain seperti pembelajaran berbasis multimedia belum dimanfaatkan oleh dosen walaupun mereka semua cukup menguasai teknologi multimedia. Metode-metode pembelajaran aktif dan kooperatif tampaknya belum banyak dikembangkan dalam pembelajaran. Media pembelajaran dan sumber referensi yang digunakan juga masih terbatas.

Penelusuran dan analisis data membawa beberapa kesimpulan pokok: pertama, ada sembilan strategi yang digunakan oleh dosen dalam membangun dan membina hubungan baik dengan mahasiswa adalah dengan cara menghadirkan diri ke hadapan mahasiswa, membuka diri dengan cara menceritakan pengalaman-pengalaman pribadi, keluarga, atau kehidupan yang terkait dengan dirinya pada mahasiswa, mengungkapkan sisi-sisi manusiawi, menunjukkan bahwa dosen ingin mengenal mahasiswa baik nama, latar belakang pendidikan, dan alamat tinggalnya, gestur atau gerak-gerik tubuh dan ekspresi wajah dosen, mengajak mahasiswa berdialog, menunjukkan kepedulian pada mahasiswa, memecah 


\section{Muna Erawati}

kebekuan dengan humor, cerita, kompetisi, dan reward, dan menaruh kepercayaan pada mahasiswa.

Kedua, determinan-determinan yang menentukan jalinan hubungan antara dosen dengan mahasiswa di kelas adalah visi mengajar yang dimiliki dosen, pandangan dosen terhadap mahasiswa, energi-kemauan-kesungguhan dosen yang dicurahkan dalam mengajar, keterampilan interpersonal dosen, jumlah dosen pengampu di kelas, dan kesan mahasiswa terhadap dosen.

Ketiga, dinamika psikologi efek jalinan hubungan baik antara dosen dengan mahasiswa dapat dijelaskan secara singkat sebagai berikut: Inisiasi rapport yang dilakukan dosen akan membentuk kesan awal yang penting bagi pembentukan hubungan positif dosen dengan mahasiswa. Hubungan yang terbina menentukan bagaimana atmosfer atau iklim di kelas. Iklim positif membawa dampak pada kenyamanan psikologis bagi mahasiswa maupun dosen. Mahasiswa menjadi lebih berminat, termotivasi, dan terlibat dalam pembelajaran. Dosen juga menjadi terjaga energinya untuk terus semangat mengajar. Akhirnya produktivitas belajar mahasiswa serta prestasi belajarnya meningkat, dan dosen pun merasa puas dengan performans mengajar di kelas.

Saran

Saran-saran meliputi: pertama, pihak pengajar diharapkan terus mengembangkan idealisme dan visi mendidik, sekaligus bersedia berdampingan, mendengar, berbincang, serta berempati dengan mahasiswa. Selain itu pengajar juga dituntut untuk selalu mengembangkan dan menemukan metode pengajaran yang paling tepat diterapkan di kelas yang berbeda karakteristiknya.

Kedua, penguatan dosen khususnya dosen tidak tetap, perlu dilakukan dengan peningkatan capacity building melalui pelatihan-pelatihan. Pelatihan yang disarankan semacam pelatihan metode pembelajaran aktif maupun kooperatif, pelatihan untuk meningkatkan keterampilan membangun rapport dengan mahasiswa juga diperlukan semacam pelatihan pemahaman rasa, pelatihan komunikasi interpersonal, pelatihan keterampilan membangun rapport dengan mahasiswa, dan sejenisnya.

Ketiga, kebijakan menempatkan dosen bergantian di kelas berkemampuan rendah perlu ditinjau kembali karena dampaknya kurang menguntungkan bagi hubungan rapport dosen dengan mahasiswa. Keempat, pengelola diharapkan dapat mengembangkan pembelajaran yang memanfaatkan sarana teknologi informasi dan komunikasi misalnya 
laboratorium bahasa, pusat akses mandiri yang dapat digunakan untuk memperkaya sumber ajar (referensi) yang lebih variatif, dan lain sebagainya. Kelima, pihak pengambil kebijakan diharapkan lebih mengakomodasi aspirasi pihak-pihak terkait, memonitor, dan mengevaluasi program agar semakin dapat memberikan layanan edukasi yang sesuai dengan standar yang diharapkan. Keenam, peneliti selanjutnya diharapkan dapat mengembangkan model pembelajaran yang berbasis pada relasi interpersonal dosen dengan mahasiswa.

\section{Daftar Pustaka}

Ainin, M. (2011). Fenomena demotivasi dalam pembelajaran Bahasa Arab di madrasah: Penyebab dan alternatif pemecahannya. Pidato Pengukuhan Guru Besar dalam Bidang Pembelajaran Fakultas Sastra (FS) UM, Kamis, 28 April 2011.

Becton, S. J. (1974). The relationship between student teacher self concept and student teacher-student rapport. Thesis (unpublished), The Graduate Faculty of Texas Tech University, USA.

Cesar, M., \& Santos, N. (2006). From exclusion to inclusion: collaborative work contributions to more inclusive learning settings. European Journal of Psychology of Education, 21, 333-346.

Fatimah, I. (2008). Tingkat profesionalitas guru pada Madrasah Aliyah Negeri di Kota Yogyakarta. Skripsi (tidak diterbitkan), Fakultas Tarbiyah Universitas Islam Negeri Yogyakarta.

Fleming, N. (2003). Establishing rapport: Personal interaction and learning. The IDEA Center. Idea Paper 39.

Golub, B., \& Jackson, M. O. (2012). How homophily affects the speed of learning and bestresponse dynamics. Paper, 1-19.

Grahe, J. E., \& Sherman, R. A. (2007). An ecological examination of rapport using a dyadic puzzle task. The Journal of Social Psychology, 147, 453-475.

Gurland, S. T., \& Grolnick, W. S. (2003). Children's expectancies, and perception of adults: Effects on rapport. Child Development, 74,1212-1224.

Gurland, S.T. \& Grolnick, W.S. (2008). Building rapport with children: Effects of adult's expected, actual, and perceive behavior. Journal of Social and Clinical Psychology, 27, 226-253.

Hakim, A. (2012). Faktor-faktor penyebab mahasiswa Jurusan Sastra Arab jarang menggunakan di SAC JSA FS UM. Skripsi (tidak diterbitkan), Jurusan Sastra Arab, Fakultas Sastra Universitas Negeri Malang.

Haynes, L. \& Backwell, B. (2010). First-class teaching: building rapport between teachers and students. Conference Proceedings, JALT, 43-51.

Indrariani, E.A. (2010). Perilaku verbal dosen dengan mahasiswa asing dalam interaksi pembelajaran Bahasa Indonesia. Laporan Penelitian, disampaikan dalam Seminar dan 


\section{Muna Erawati}

Lokakarya: Penelitian Tindakan Kelas dalam Perspektif Etnografi, Program Magister Linguistik Universitas Diponegoro Semarang, 2 Oktober 2010.

Kurniawati, D. (2011). Hubungan antara gaya komunikasi guru dengan prestasi akademik siswa (Studi korelasi gaya komunikasi guru dengan prestasi akademik siswa Kelas VIII pada mata pelajaran Bahasa Indonesia di SMP Negeri 2 Pakem Yogyakarta). (Skripsi tidak diterbitkan), Jurusan Ilmu Komunikasi Fisip UPN “Veteran” Yogyakarta.

Lyons, E., \& Coyle, A. (Eds.). (2007). Analysing qualitative data in psychology. Los Angeles: Sage Publications.

Norfolk, T., Birdi, K., \& Walsh, D. (2007). The role of empathy in establishing rapport in the consultation; A new model. Medical Education, 41, 690-697.

Nurhidayati. (2002). Jenis dan sebab kesulitan yang dihadapi oleh mahasiswa dalam menyimak teks. Laporan Penelitian, Jurusan Sastra Arab, Fakultas Sastra, Universitas Negeri Malang.

Ormrod, J.E. (2008). Psikologi pendidikan: Membantu siswa tumbuh dan berkembang Jilid II. Judul asli: Educational Psychology Developing Learners - diterj. oleh: Amitya Kumara. Jakarta: Erlangga.

Poerwandari, E.K. (1998). Pendekatan kualitatif dalam penelitian psikologi. Jakarta: Lembaga Pengembangan Sarana Pengukuran dan Pendidikan Psikologi Fakultas Psikologi Universitas Indonesia.

Sharifi,H-P. (2008). The introductory study of Gardner's multiple intelligence theory, in the field of lesson subjects and the students' compatibility. Quarterly Journal of Educational Innovations, 24, 11-20.

Sharpley, C.F., Fairnie, E., Tabary-Collins, Bates, \& Lee, P. (2000). The use of counselor verbal modes and client-perceived rapport. Counseling Psychology Quarterly, 13, 99-116.

Starcher, K. (2011). Intentionally building rapport with students. College Teaching, 59: 162.

Susetyo, Y.F. (2004). Perubahan perilaku mengajar yang humanis guru sekolah dasar setelah menjalani pelatihan berpikir positif. Laporan Penelitian, Fakultas Psikologi Universitas Gadjah Mada Yogyakarta.

Swenson, E. (2010). Rapport in the classroom. Paper, This paper was completed and submitted in partial fulfillment of the Master Teacher Program, a 2-year faculty professional development program conducted by the Center for Teaching Excellence, United States Military Academy, West Point, NY.

Zuraikha \& Kuswandono, S. (2010). Persepsi dan harapan mahasiswa dan dosen terhadap pembelajaran keterampilan. Abdimas, 6, 1-7. 